\title{
Tubular reabsorption of calcium in normal and hypercalciuric subjects
}

\author{
M. PEACOCK AND B. E. C. NORDIN \\ From the Medical Research Council, Mineral Metabolism Research Unit, \\ General Infirmary, Leeds, England
}

SYNOPSIS Tubular reabsorption and excretion of calcium were studied at different levels of filtered calcium by means of calcium infusion in normal and hypercalciuric subjects and in patients with idiopathic nephrolithiasis.

Calcium reabsorption and excretion rose linearly with filtered load and in no case was a maximum tubular reabsorptive capacity for calcium reached.

No decrease in tubular reabsorption of calcium was found in hypercalciuric as compared with normocalciuric subjects, and no difference in tubular reabsorption was found between patients with idiopathic nephrolithiasis and normal subjects.

Calcium excretion and reabsorption calculated from the endogenous creatinine clearance during calcium infusion were virtually identical with the corresponding values calculated from the inulin clearance.

Hypercalciuria, an increased excretion of calcium in the urine, may be due to an increase in the filtered load of calcium or to a reduction in calcium reabsorption or a combination of the two. When it is associated with hypercalcaemia it can reasonably be attributed to an increase in the filtered load of calcium, but in most cases of hypercalciuria, particularly those of the so-called idiopathic variety, the serum calcium has been found to lie within the normal range (Henneman, Benedict, Forbes, and Dudley, 1958). The cause of this type of hypercalciuria, which is a feature of at least $60 \%$ of patients with idiopathic nephrolithiasis (Flocks, 1939), is unknown, but Jackson and Dancaster (1959) concluded from their studies that it was probably of tubular origin and suggested that the increased absorption of calcium from the gut, which is a characteristic feature of this condition (Henneman et al., 1958), was compensatory. Edwards and Hodgkinson (1965) also considered that the hypercalciuria was probably tubular.

In view of the difficulty of detecting the small differences in tubular reabsorption of calcium which may be present when plasma calcium levels are in the normal range, we have infused calcium intravenously into normocalciuric and hypercalciuric subjects, with and without renal stones, and determined the excretion and reabsorption of calcium at

Received for publication 19 October 1967. different levels of filtered load. Our object was to establish whether or not the hypercalciuria of these cases is attributable to decreased renal tubular reabsorption of calcium or to an increase in filtered load (Kleeman, Bernstein, Rockney, Dowling, and Maxwell, 1961).

\section{MATERIALS AND METHODS}

CASES STUDIED We report the results (Table I) of calcium infusions in seven normal subjects, all members of staff (five men and two women), and 11 cases of idiopathic nephrolithiasis (eight men and three women). For purposes of classification we have defined hypercalciuria in accordance with the suggestion of Hodgkinson and Pyrah (1958), namely, a urinary calcium excretion of over $300 \mathrm{mg}$ per 24 hours in a male and over $250 \mathrm{mg}$ per 24 hours in a female. On this basis one of the normal subjects and eight of the renal stone patients had persistent hypercalciuria.

A further nine subjects (seven men and two women) with various disturbances of calcium metabolism received simultaneous calcium and inulin infusions for the comparison of endogenous creatinine and inulin clearances. These are reported separately.

PROCEDURE The subjects were studied at rest in a metabolic ward after an overnight fast. Water was given before and during the infusion to give a urine flow of at least $3 \mathrm{ml} / \mathrm{min}$. There was no dietary preparation.

Each study began with a timed urine collection and a blood sample taken at the mid point of this collection. 
TABLE I

INITIAL AND DERIVED DATA ON CONTROLS AND STONE FORMERS

\begin{tabular}{|c|c|c|c|c|c|}
\hline Subject & $\begin{array}{l}\text { Filtered } \\
\text { Calcium } \\
(m g / 100 \\
m l G . F .)\end{array}$ & $\begin{array}{l}\text { Excreted } \\
\text { Calcium } \\
\text { ( } m g / 100 \\
\text { ml G.F.) }\end{array}$ & $\begin{array}{l}\text { Calcium } \\
\text { Threshold } \\
\text { (mg/100 } \\
\text { ml G.F.) }\end{array}$ & $\begin{array}{l}\text { Slope of } \\
\text { Excreted } \\
\text { on Filtered } \\
\text { Calcium }\end{array}$ & $\begin{array}{l}\text { Mean } \\
\text { Glomerular } \\
\text { Filtration } \\
\text { Rate } \\
\text { (Creatinine } \\
\text { Clearance } \\
\text { ml/min) }\end{array}$ \\
\hline $\begin{array}{l}\text { Controls } \\
\text { P.F. }{ }^{1} \\
\text { P.K. } \\
\text { J.M. } \\
\text { D.M. } \\
\text { G.R. } \\
\text { L.S. } \\
\text { A.S. }\end{array}$ & $\begin{array}{l}5 \cdot 00 \\
6 \cdot 30 \\
5 \cdot 90 \\
6 \cdot 20 \\
6 \cdot 50 \\
5 \cdot 40 \\
5 \cdot 80\end{array}$ & $\begin{array}{l}0.35 \\
0.07 \\
0.01 \\
0.13 \\
0.10 \\
0.35 \\
0.09\end{array}$ & $\begin{array}{l}4 \cdot 0 \\
6 \cdot 4 \\
5 \cdot 4 \\
5 \cdot 5 \\
6 \cdot 4 \\
4 \cdot 6 \\
5 \cdot 0\end{array}$ & $\begin{array}{l}0.34 \\
0.58 \\
0.43 \\
0.43 \\
0.59 \\
0.47 \\
0.35\end{array}$ & \begin{tabular}{r|}
172 \\
153 \\
119 \\
122 \\
138 \\
94 \\
87
\end{tabular} \\
\hline $\begin{array}{l}\text { Stone } \\
\text { formers } \\
\text { M.A. }{ }^{1} \\
\text { J.D.1 } \\
\text { J.K. }{ }^{1} \\
\text { M.L.1 } \\
\text { F.S. }{ }^{1} \\
\text { J.S. } \\
\text { E.S. }{ }^{1} \\
\text { K.S. } \\
\text { A.T.1 } \\
\text { W.T.1 } \\
\text { E.V. }\end{array}$ & $\begin{array}{l}5.80 \\
5.80 \\
5.50 \\
5.60 \\
5.80 \\
5 \cdot 10 \\
5.90 \\
5.20 \\
6 \cdot 10 \\
5.90 \\
5.90\end{array}$ & $\begin{array}{l}0.13 \\
0.14 \\
0.34 \\
0.24 \\
0.22 \\
0.12 \\
0.20 \\
0.12 \\
0.16 \\
0.38 \\
0.27\end{array}$ & $\begin{array}{l}5 \cdot 4 \\
5.5 \\
4.9 \\
5.2 \\
5.7 \\
5 \cdot 0 \\
5 \cdot 7 \\
4 \cdot 8 \\
5.9 \\
5 \cdot 1 \\
5 \cdot 2\end{array}$ & $\begin{array}{l}0.41 \\
0.54 \\
0.50 \\
0.37 \\
0.62 \\
0.47 \\
0.64 \\
0.35 \\
0.70 \\
0.55 \\
0.42\end{array}$ & $\begin{array}{r}178 \\
116 \\
136 \\
77 \\
118 \\
108 \\
112 \\
98 \\
98 \\
96 \\
101\end{array}$ \\
\hline
\end{tabular}

${ }^{1}$ Hypercalciuric.

'Identical with ultrafiltrable calcium.

Ten per cent calcium gluconate was then infused intravenously with the aid of an infusion pump for four to six hours to give a rate of about $200 \mathrm{mg}$ calcium infused per hour.

In the inulin studies, a priming dose of inulin, $50 \mathrm{mg}$ per $\mathrm{kg}$, was followed by an infusion of $5 \%$ inulin made up in $10 \%$ calcium gluconate to give a rate of $1 \mathrm{~g}$ of inulin and $200 \mathrm{mg}$ calcium per hour.

Consecutive timed urine samples were collected and a blood sample was taken at the mid point of each urine sample.

Calculations The calcium filtered $\left(\mathrm{Ca}_{\mathrm{F}}\right)$, excreted $(\mathrm{CaE})$, and reabsorbed $\left(\mathrm{Ca}_{\mathrm{R}}\right)$ are all expressed in milligrams per $100 \mathrm{ml}$ of glomerular filtrate. In these terms, $\mathrm{CaF}_{\mathrm{F}}$ is synonymous with the plasma ultrafilterable calcium concentration $\left(\mathrm{UF}_{\mathrm{Ca}}\right.$ ) in $\mathrm{mg}$ per $100 \mathrm{ml}$; $\mathrm{Ca}_{\mathrm{E}}$ is the product of the urinary calcium/inulin ratio and the plasma inulin. This simplified formula is derived as follows. Since the calcium/inulin clearance ratio is the proportion of filtered calcium that appears in the urine, and since the ultrafilterable calcium concentration is the same as the filtered load of calcium per $100 \mathrm{ml}$ of glomerular filtrate, then the product of the two is the amount of calcium excreted per $100 \mathrm{ml}$ of glomerular filtrate. Thus:

$$
\mathrm{Caz}_{\mathrm{a}}=\frac{\mathrm{C}_{\mathrm{Ca}}}{\mathrm{C}_{\mathrm{in}}} \times \mathrm{UF}_{\mathrm{Ca}}
$$

where $C_{C a}$ and $C_{1 n}$ represent the calcium and inulin clearances.
But

$$
\frac{\mathrm{C}_{\mathrm{Ca}}}{\mathrm{C}_{\mathrm{in}}}=\frac{\mathrm{U}_{\mathrm{Ca}} \times \mathrm{P}_{\mathrm{in}}}{\mathrm{UF}_{\mathrm{Ca}} \times \mathrm{U}_{\mathrm{in}}}
$$

where $P_{\text {in }}$ and $U_{\text {in }}$ represent plasma and urinary inulin concentrations and $U_{\mathrm{Ca}}$ urine calcium concentration in mg per $100 \mathrm{ml}$.

Therefore

which simplifies to:

$$
\mathrm{CaE}_{\mathrm{E}}=\frac{\mathrm{U}_{\mathrm{Ca}} \times \mathrm{P}_{\mathrm{in}}}{\mathrm{UF}_{\mathrm{Ca}} \times \mathrm{U}_{\mathrm{in}}} \times \mathrm{UF}_{\mathrm{Ca}}
$$

or (with creatinine)

$$
\mathrm{Ca}_{\mathrm{E}}=\frac{\mathrm{U}_{\mathrm{Ca}} \times \mathrm{P}_{\mathrm{in}}}{\mathrm{U}_{\mathrm{in}}}
$$

$$
\mathrm{Ca}_{\mathbf{E}}=\frac{\mathrm{U}_{\mathrm{Ca}} \times \mathrm{P}_{\mathrm{cr}}}{\mathbf{U}_{\mathrm{cr}}}
$$

where $P_{\mathrm{cr}}$ and $U_{\mathrm{cr}}$ represent plasma and urinary creatinine $\vec{\omega}_{\omega}$ concentration in $\mathrm{mg}$ per $100 \mathrm{ml}$. $\mathrm{Ca}_{\mathrm{R}}$ is simply $\mathrm{Ca}_{\mathrm{r}}$ minus CaE.

The slope of $\mathrm{CaF}_{\mathrm{E}}$ on $\mathrm{Ca}_{\mathrm{F}}$ was determined by theo method of least squares since inspection of the data showed that the plot was linear. The theoretical calcium $\vec{Z}$ threshold concentration $\left(\mathrm{Ca}_{\mathrm{T}}\right)$ is the value of $\mathrm{Ca}_{\mathrm{F}}$ at which $\mathrm{CaE}_{\mathrm{E}}$ is zero and is also expressed in $\mathrm{mg}$ per $100 \mathrm{ml}^{\mathrm{K}}$ of glomerular filtrate. When multiplied by the meance glomerular filtration rate in millilitres per minute and divided by 100 it represents the threshold filtered load in milligrams per minute.

METHODS Ultrafiltration of plasma samples was per-̄ formed by the method of Toribara, Terepka, and Deweyڤ (1957) as modified by Nordin and Smith (1965). Plasma $\triangle$ and urine calcium were measured by the AutoAnalyzer $\overrightarrow{\vec{A}}$ using cresolphthalein complexone indicator (Kessler and $\mathrm{O}$ Wolfman, 1964; Fales, 1964). Plasma and urinary creatinine were measured by the AutoAnalyzer (Chasson Grady, and Stanley, 1961). Inulin was measured in plasma (after protein precipitation) and in urine by the AutoAnalyzer by a method based on that of Roe, Epstein, and Goldstein (1949).

\section{RESULTS}

In nine subjects in whom simultaneous calcium and inulin infusions were performed, the endogenous $\frac{D}{9}$ creatinine clearance was compared with the inulin clearance (Fig. 1). The coefficient of correlation was $\tilde{O}$ very high $(\mathrm{r}=0.99)$ with a mean $\mathrm{Ca}$ (creatinine) $/ N$ $\mathrm{Ca}$ (inulin) ratio that did not differ significantly $O$ from unity. The coefficient of correlation between $\omega$ urine/plasma ratios for creatinine and inulin was 0.99 in these same studies with a $\mathrm{Ccr} / \mathrm{Cin}$ ratio very close to unity.

All subsequent data are based, therefore, on the $\stackrel{\oplus}{+}$ endogenous creatinine clearance.

The results of the individual infusions in the seven $\frac{\overrightarrow{0}}{\bar{D}}$ normal subjects are shown in Figure 2. Calcium $\stackrel{?}{\mathscr{Q}}$ excretion rose linearly with filtered calcium in all $\stackrel{\square}{\square}$ seven subjects, the gradient ranging from 0.34 to 0.59 . The intercepts of these slopes on the $x$-axis, 


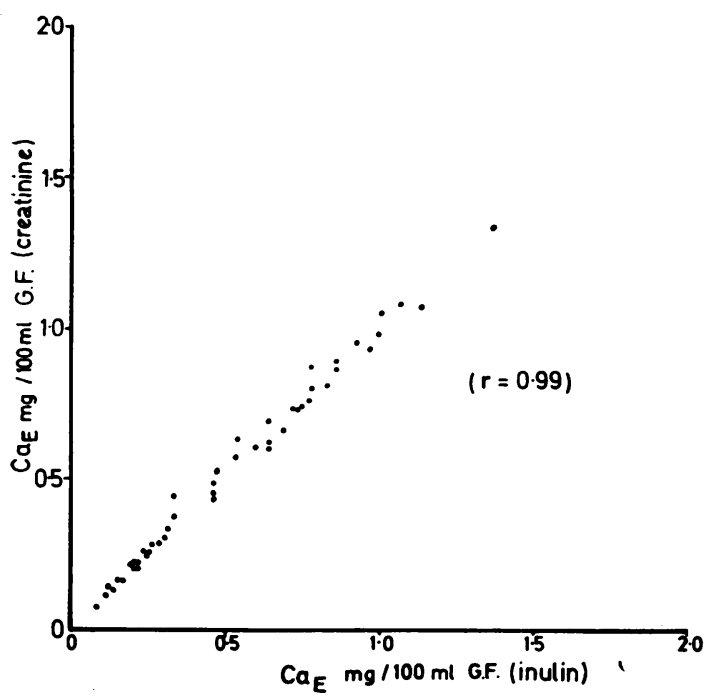

FIG. 1. The relation between calcium excreted per $100 \mathrm{ml}$ of inulin clearance and calcium excreted per $100 \mathrm{ml}$ of creatinine clearance in nine separate calcium infusion studies. which may be regarded as the theoretical calcium threshold, lay between $4.0 \mathrm{mg}$ and $6.3 \mathrm{mg}$ per $100 \mathrm{ml}$ glomerular filtrate. The results of the individual infusions in the 11 stone cases are shown in Figure 3. Calcium excretion rose linearly with filtered calcium in all 11 cases, thegradient ranging from 0.35 to 0.70 . The theoretical calcium threshold ranged from 5.0 to $6.0 \mathrm{mg}$ per $100 \mathrm{ml}$ glomerular filtrate. The mean slopes and thresholds are shown in Figs. 4 and 5 and in Table II. There is no significant difference between the mean slopes of the controls $(0.46)$ and of the stone-formers (0.51) (Fig. 4) and the mean thresholds of the two groups are the same $(5.32 \mathrm{mg}$ per $100 \mathrm{ml}$ glomerular filtrate (Fig. 5).

The cases have also been classified into normocalciuric and hypercalciuric subjects according to their 24-hour urine calcium on a free diet as defined above, one of the normals and eight of the renal stone cases being hypercalciuric. As shown in Figs. 4 and 5 and Table II, there was no significant difference between the gradients or thresholds of normocalciuric and hypercalciuric subjects.

The theoretical calcium threshold data have also been expressed in milligrams per minute in Fig. 5 and Table II. Expressed in these terms the range is from 4.0 to $9.7 \mathrm{mg}$ per minute and the range of the means 6.0 to 6.7 per minute according to the way the cases

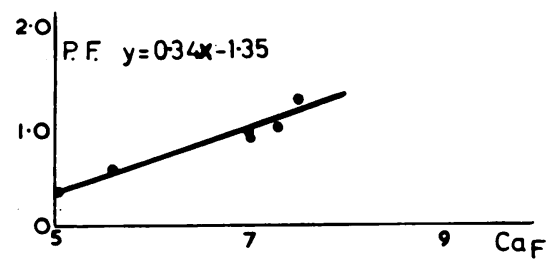

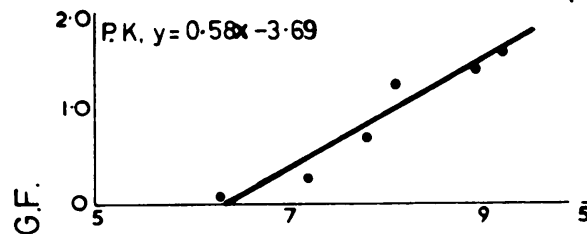

J.M. $y=0 \cdot 43 x-2 \cdot 34$
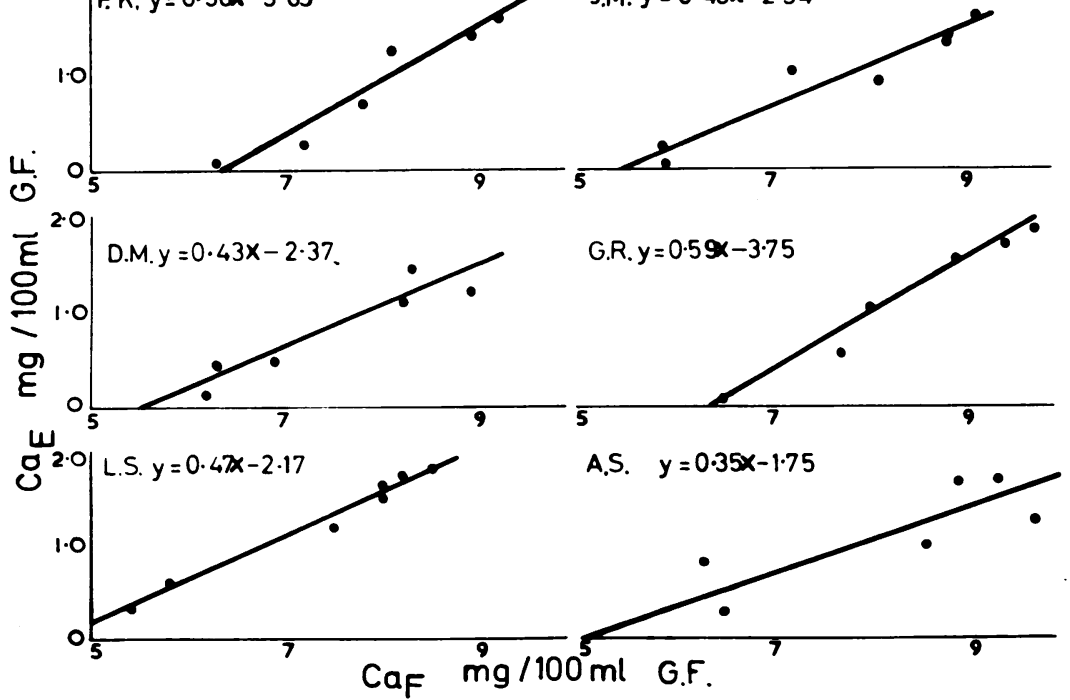

FIG. 2. The relation between filtered and excreted calcium in seven infusion studies on normal subjects. 


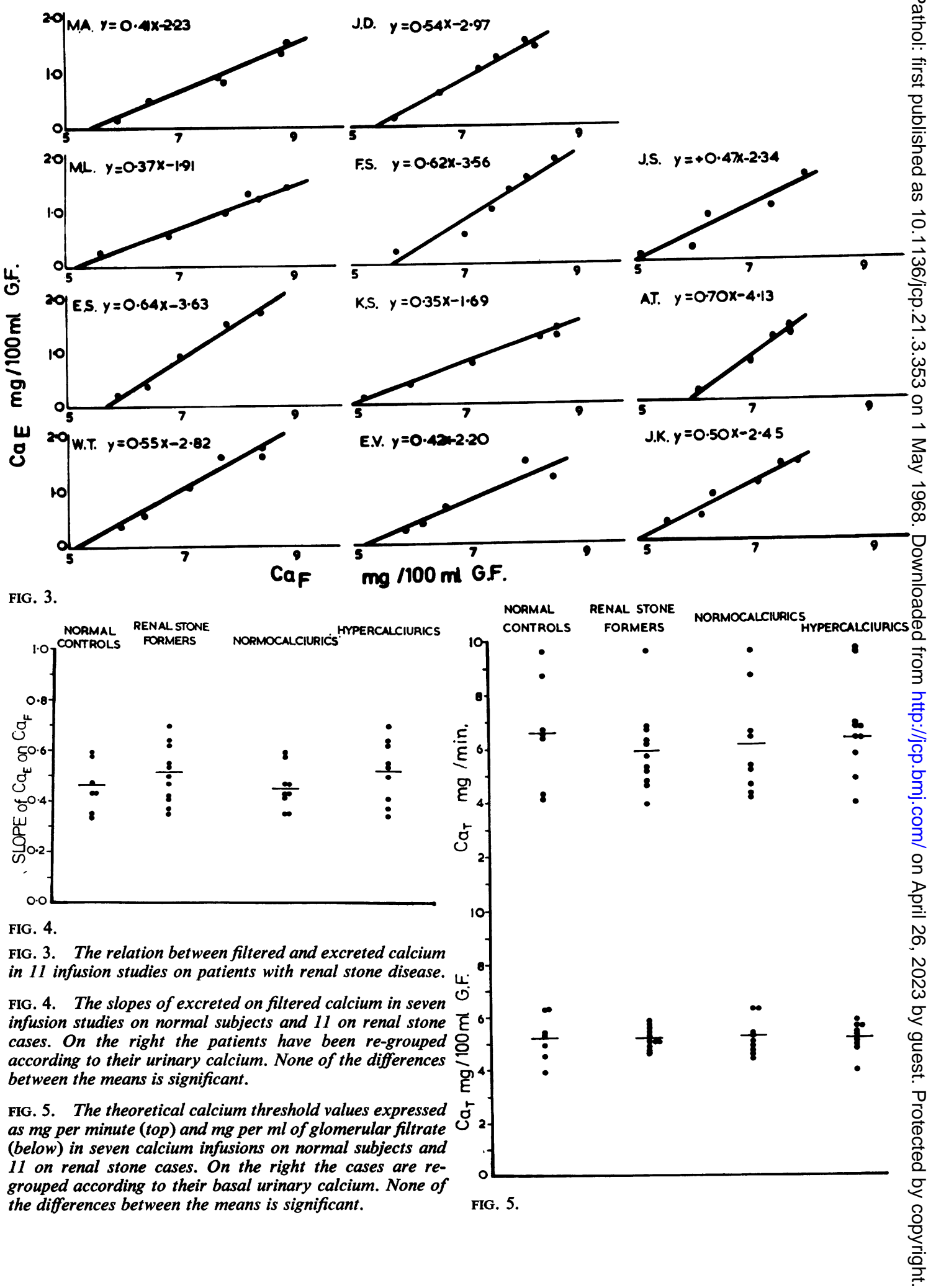


TABLE II

RELATION BETWEEN EXCRETED CALCIUM AND FILTERED CALCIUM AND THEORETICAL CALCIUM THRESHOLD CALCULATED FROM THE MEANS OF THE INDIVIDUAL SUBJECTS Series

\begin{tabular}{|c|c|c|c|}
\hline $\begin{array}{l}\text { No. of } \\
\text { Cases }\end{array}$ & $\begin{array}{l}\text { Mean of } \\
\text { Slopes of } \mathrm{Ca}_{\mathrm{E}} \\
\text { on CaF } \\
\pm \mathrm{SD} \\
(\mathrm{mg} / 100 \mathrm{ml} \\
\text { G.F. })\end{array}$ & $\begin{array}{l}\text { Mean of Car } \\
\text { Values } \pm S D \\
(\mathrm{mg} / 100 \mathrm{ml} \\
\text { G.F. })\end{array}$ & $\begin{array}{l}\text { Mean of } \mathrm{Ca}_{T} \\
\text { Values } \pm S D \\
(\mathrm{mg} / \mathrm{min})\end{array}$ \\
\hline
\end{tabular}

\begin{tabular}{llllll}
\hline Control & 7 & $0.46 \pm 0.10$ & $5.32 \pm 0.88$ & $6.74+2.03$
\end{tabular}

$\begin{array}{llllll}\text { Renal stone } & 11 & 0.51 \pm 0.12 & 5.32 \pm 0.36 & 6.01 \pm 1.50\end{array}$

$\begin{array}{lllll}\text { Normocalciuric } 9 & 0.45 \pm 0.09 & 5.37 \pm 0.52 & 6.20 \pm 1.90\end{array}$

$\begin{array}{lllll}\text { Hypercalciuric } & 9 & 0.52 \pm 0.12 & 5.27 \pm 0.58 & 6.39 \pm 1.56\end{array}$

are grouped. None of the group differences is significant.

\section{DISCUSSION}

We have found no significant difference between the tubular reabsorption of calcium in normocalciuric and hypercalciuric subjects when the filtered load of calcium is increased, and we conclude that most cases of 'idiopathic hypercalciuria' must be due to an increased filtered load of calcium. The filtered load is, however, the product of the ultrafilterable plasma calcium and the glomerular filtration rate and can be raised by an increase in either or both. Thus an increase in glomerular filtration rate of only $5 \%$ or in ultrafilterable calcium of only $0.25 \mathrm{mg} \%$ over 24 hours would be enough to raise the urinary calcium from say, 200 to $400 \mathrm{mg}$ a day, yet neither of these increases could be easily detected between individuals. However, hypercalciuric individuals are known to absorb an abnormally high proportion of their dietary calcium (Henneman et al., 1958) and a slightly raised plasma calcium concentration due to high absorption of calcium probably explains their hypercalciuria (Caniggia, Gennari, and Cesari, 1965). This might only be apparent in post-prandial blood samples.

The apparently reduced tubular reabsorption of calcium reported in stone cases by Smith and MacKenzie (1966) is probably due to their lack of normal controls. Recalculation of their data show that it is rather their osteoporotic cases, with which the stone cases were compared, which have a high reabsorption of calcium. This in itself is of considerable interest.

The rather wide range of slopes of excreted on filtered calcium in both the normal and stoneforming groups could have various explanations but we suspect it is largely attributable to variations in parathyroid activity. The data of Kleeman et al. (1961) suggest that the slope observed in any given individual reflects his parathyroid activity at that time, steep slopes representing low parathyroid activity and vice versa.

Our results are expressed in terms of a standard volume of glomerular filtrate $(100 \mathrm{ml})$ in the same way as Pitts, Ayer, and Schiess (1949) have done for bicarbonate. This does not affect the gradient of a plot of excreted or reabsorbed on filtered calcium and so does not affect our main observation. It does affect the calcium threshold to the extent that the individual glomerular filtration rate differs from 100 , but in so doing it eliminates differences attributable to body size and renal function which are irrelevant to this study. The calcium excreted per $100 \mathrm{ml}$ of glomerular filtrate is, moreover, a convenient standard way of expressing calcium excretion which can be applied to random samples of plasma and urine even when the glomerular filtration rate is not known.

Doubts have been expressed about the value of endogenous creatinine clearance as a measure of the glomerular filtration rate (Wrong, 1963; Reubi, 1963; Berlyne, Varley, Nilwarangkur, and Hoerni, 1964), because of the difficulty in measuring true plasma creatinine and because of the possible active secretion of creatinine by the tubules. Our results in nine studies, however, show that calcium excretion calculated from the endogenous creatinine clearance is virtually identical with that calculated from the inulin clearance. It seems that if sufficient care is taken to avoid analytical errors, especially by the use of AutoAnalyzer techniques, then the endogenous creatinine and inulin clearances are virtually the same (Doolan, Alpen, and Theil, 1962; Tobias, McLaughlin, and Hooper, 1962; Malamos, Dontas, Koutras, Marketos, Sfontouris, and Papanicolaou, 1966).

Neither Kleeman et al. (1961) nor we in this study have observed a maximum tubular reabsorptive capacity for calcium, and we agree with them that excreted and reabsorbed calcium rise linearly with filtered load during calcium infusion. We interpret this to mean that when, in any given individual, the plasma calcium is raised above the basal level a constant proportion of the increase in filtered load is reabsorbed. Recent studies indicate that calcium is reabsorbed by an active process (Chen and Neuman, 1955a and 1955b; Walser and Browder, 1959) and this would seem to be a gradient-time limited system, in the terminology of Pitts (1963), rather than Tm limited. Thus tubular reabsorption of calcium ranges from 30 to $66 \%$ of the additional filtered load over and above the theoretical calcium threshold for the individual.

The results presented in this paper have not revealed any consistent change in tubular reabsorption of calcium in hypercalciuric subjects as com- 
pared to normocalciuric subjects, nor have they revealed the existence of a maximum tubular reabsorptive capacity for calcium ( $\mathrm{TmCa}$ ) as postulated by Copp, McPherson, and McIntosh (1960)

\section{REFERENCES}

Berlyne, G. M., Varley, H., Nilwarangkur, S., and Hoerni, M. (1964). Lancet, 2, 874.

Caniggia, A., Gennari, C., and Cesari, L. (1965). Brit. med. J., 1, 427.

Chasson, A. L., Grady, H. J., and Stanley, M. A. (1961). Amer. J. clin. Path., 35, 83

Chen, P. S. Jr., and Neuman, W. F. (1955a). Amer. J. Physiol., 180, 623.

Copp, D. H., McPherson, G. D., and McIntosh, H. W. (1960). Metabolism, 9, 680 .

Doolan, P. D., Alpen, E. L., and Theil, G. B. (1962). Amer. J. Med., $32,65$.

Edwards, N. A., and Hodgkinson, A. (1965). Clin. Sci., 29, 327.

Fales, F. W. (1964). Clin. Chem., 10, 549.

Flocks, R. H. (1939). J. Amer. med. Ass., 113, 1466.

Henneman, P. H., Benedict, P. H., Forbes, A. P., and Dudley, H. R (1958). New Engl.J. Med., 259, 802.
Hodgkinson, A., and Pyrah, L. N. (1958). Brit. J. Surg., 46, 10.

Jackson, W. P. U., and Dancaster, C. (1959). J. clin. Endocr., 19, 658. 으

Kessler, G., and Wolfman, M. (1964). Clin. Chem., 10, 686.

Kleeman, C. R., Bernstein, D., Rockney, R., Dowling, J. T., and $\overrightarrow{\bar{Z}}$ Maxwell, M. H. (1961). In The Parathyroids, edited by R. O. Greep and R. V. Talmage, p. 353. Thomas, Springfield, Ill.

Malamos, B., Dontas, A. S., Koutras, D. A., Marketos, S., Sfontouris, J., and Papanicolaou, N. (1966). Lancet, 1, 943.

Nordin, B. E. C., and Smith, D. A. (1965). Diagnostic Procedures in Disorders of Calcium Metabolism. Churchill, London.

Pitts, R. F. (1963). Physiology of the Kidney and Body Fluids. Year $\stackrel{\mathbb{D}}{2}$ Book Medical Publishers, Chicago.

—, Ayer, J. L., and Schiess, W. A. (1949). J. clin. Invest., 28, 35.

Reubi, F. C. (1963). Clearance Tests in Clinical Medicine. Thomas, $\overrightarrow{0}$ Springfield, Ill.

Roe, J. H., Epstein, J. H., and Goldstein, N. P. (1949). J. biol. Chem., $178,839$.

Smith, D. A., and MacKenzie, J. C. (1966). In Calcified Tissues, 1965, edited by H. Fleisch, H. J. J. Blackwood, and M. Owen. p. $211 . \bar{O}$ Springer, Berlin and Heidelberg.

Tobias, G. J., McLaughlin, R. F., Jr., and Hooper, J., Jr. (1962). i New Engl. J. Med., 266, 317.

Toribara, T. Y., Terepka, A. R., and Dewey, P. A. (1957). J. clin. Invest., 36, 738.

Walser, M., and Browder, A. A. (1959). Ibid., 38, 1404.

Wrong, O. M. (1963). In Renal Disease, edited by D. A. K. Black, p. 440. Blackwell, Oxford. 